\title{
Controversies Around the System, Organisation and Curriculum Structure of Secondary School Education in Poland, in the Years 1944-1948
}

\begin{abstract}
A new form of government of the Polish state was combined with its rather intensive influence on the character of the educational system, including general secondary schools. That time is distinguished by numerous controversies, which then appeared in various social circles, political parties, and referred to the constitutional and organizational structure as well as the program structure of this school level. In the first years the controversies were more of an evolutionary concepts for the Polish route to socialism were still possible. After 1948 there was no more room for discussion; the decisions about this sphere were also made by one group - the people related to the communist party (Pol. abbr. PZPR).

Already right after the cessation of war activities, the tendencies leading to the centralization of education management were noticeable, and consequently, ever more intense influence of the government of the working classes (lub the people's government) on the functioning of schools, but, above all, on the teaching content. The process of centralization was linked with the so-called democratization process of school i.e., the question, of which the ruling communists made their priority. A consequence of democratization of the general secondary school and rendering it a tool for the manufacture of future citizens - devoted to and subjected to the government of the working classes - was the aspiration for closing private general secondary school, and also the expulsion of religion from school. Such changes, falsely justified by the necessity to observe the principle of freedom of conscience and confession, led to the secularization of the school system. The discussed expulsion of the Church from schools, and at the same time from the sphere of educating a young generation, was supposed to serve the formation of a new socialist society in the future.
\end{abstract}

Keywords: schools in Poland, school organisation, history of education

\section{The new Polish system and its impact on the character of secondary school education}

The first period of the Polish People's Republic was a time, when trends towards centralisation were visible in the scope of education organisation and management. All issues related with education and upbringing and all divisions of the school system were man- 
aged by the Minister of Education; only the matters of religion and culture were not included in his responsibilities. Although regional educational authorities were maintained: district schoolboards in voivodeships and school inspectorates in poviats, both schoolboards and inspectorates were directly subject to the Minister of Education ${ }^{1}$. This centralism in the Polish educational policy was quite subdued. In comparison with the consecutive period, it was rather an evolution towards intensification of the communist system and in the following years, after 1948, it took the form of a revolution.

Postulated so-called school democratisation process was already stipulated in the socalled programme declaration of the Polish Worker's Party in November 1943 entitled: "What are we fighting for?". It is written therein, among others, that: "School and school organisation from the lowest to the highest levels based on democratic principles must ensure the possibility of free education of students from workers' and farmers' families at all levels of education. Universal and obligatory education should cover all youth under the age of 16. Knowledge is a national good, the state provides the not well-off, yet, talented youth with a possibility to study at universities by paying sufficient scholarships ${ }^{2}$." Also the Manifesto of the Polish Committee of National Liberation stated that: "One of the most important tasks of the Polish Committee of National Liberation shall be the reconstruction of education and ensuring free education at all levels in the liberated areas. Polish intelligence decimated by Germans and in particular, academics and arts personalities shall be provided with special care ${ }^{3}$."

In the period after the Lódź Education Conference held on 18-22 June 1945, teaching communities expected significant changes in the Polish education system that were supposed to be introduced in compliance with agreements made at the convention. However, the educational policy did not undertake implementation of the aforementioned agreements. They were not properly included in the "Instruction on organisation of the school year 1945/46"

This lack of coherent approach in the Ministry's educational policy after the Conference revived the dispute and controversies regarding the school model. Many arguments focused on political parties ${ }^{5}$ and discussions regarding educational reform and were brought up during consecutive meetings, conferences and conventions.

The main political party that attempted to implement the crucial educational policy in the post-war Poland was of course the Polish Workers' Party. It stipulated its programme,

${ }^{1}$ PĘCHERSKI, M., ŚWIĄTEK, M., Organizacja oświaty w Polsce w latach 1917-1969. Podstawowe akty prawne, Warsaw 1972.

2 The History Department of the Central Committee of the Polish United Workers' Party: W dziesiątą rocznicę powstania Polskiej Partii Robotniczej. Materiały i dokumenty, Warsaw 1952, p. 193; As cited in: MACIASZEK, M., Treść ksztatcenia i wychowania w reformach szkolnych PRL, Warsaw 1980.

${ }^{3}$ Manifesto of the Polish Committee of National Liberation, Official Journal of the Department of Education 1944/no. 1.

${ }^{4}$ Instruction of 16 July 1945 on the organisation of the school year 1945/46 in secondary schools, Official Journal, the Ministry of Education 1945/no. 2/item 62.

${ }^{5}$ MAUERSBERG, S., Reforma szkolnictwa w Polsce w latach 1944-1948, p 107-113. 
however, it did not allow itself to fully implement thereof in 1945, as it tried to enforce the elements accepted not only by the communists. It resulted from the fact that the impact on the education was limited by the coalition government and the Minister Czesław Wycech from the Polish People's Party.

Full curriculum was developed in May 1945 as a summary of the national council of teachers members of the Polish Workers' Party. Six curriculum theses were adopted at that time:

1) basing the school system on the principles of uniformity, universality, statehood and free education;

2) setting the lower limit of the school obligation at seven years old;

3) extending the compulsory education to eight years;

4) basing youth education on two types of schools: eight year elementary school and three year secondary school (high school or vocational school);

5) development of vocational education;

6) implementation of the slogan: not one school-aged child outside the school ${ }^{6}$.

Soon enough it turned out the curriculum is not realistic. In particular, as the education authorities were not able to establish eight year schools due to a lack of buildings and teachers. Furthermore, complete omission of already existing lower secondary schools in the theses complicated reliable assessment of the facts; and after all, those schools educated elites and employed the best teachers. Moreover, establishing three year vocational schools turned out to be a difficult task, at least in the first years of the Polish People's Republic, due to the unwillingness of more talented students to this type of schools and financial difficulties of the state. Nevertheless, the disregard for lower secondary schools indicating communists' unwillingness thereto and care for vocational schools were important signals in then educational policy, which returned in years to come in a form of a revolution ${ }^{7}$.

On 7-8 October 1945, the $2^{\text {nd }}$ Conference of teachers, members of the Polish Workers' Party held a meeting, during which the importance of education for the communist authorities and the attention devoted thereto could have been noticed. It was stated that the Polish Teachers' Union, which proclaimed a policy of neutrality in the period the Polish Committee of National Liberation and the Provisional Government were in place, started acting under the influence of Mikołajczyk and Polish People's Party. Also the Polish Socialist Party had quite a significant support among teachers, whereas the Polish Worker's Party's influence was significantly limited ${ }^{8}$. In the final resolutions of the Conference, the government was called on to establish and implement a new school act stipulating 8 year obligatory elementary schools and obligatory youth education until 18 years of age.

${ }^{6}$ AAN PPR, 295/X/19, c. 11a; As cited in: KOSIŃSKI, K., O nowa mentalność. Życie codzienne w szkotach 1945-1956, Warsaw 2000, p 37-38.

7 Ibidem, p. 38.

${ }^{8}$ MAUERSBERG, S., op. cit., p.107. 
Furthermore, it was called on to advance and end works on curricula based on the academic view of the world and compliant with the progressive tradition of Polish democracy ${ }^{9}$.

Other position regarding the reconstruction of education and school reform was presented by the Polish Socialist Party's teachers during all-Poland convention held in Warsaw, on 16-17 November 1945. They demanded independent, secular, free, uniform and obligatory school for all children. The said teachers, in the presence of the Prime Minister Edward Osóbka-Morawski postulated 10-form universal lower secondary schools, the main author of which was the chairman of the convention, Teofil Wojeński. In the ideological declaration adopted by the convention the teachers-members of the Polish Socialist Party demanded prioritising educational needs in the state budget ${ }^{10}$.

The situation in which civil servants: employees of the Ministry of Education, trade union and education activists represented approaches to educational issues of various political parties resulted in instable and diverse attitude inside the Ministry. Minister Cz. Wycech, Director W. Schayer, President of the Polish Teachers' Union K. Maj, as education activists of "Rocha" and TON were authors and supporters of people's and teachers' educational conceptions from the occupation times. This relation continued in the period of the Polish People's Republic and since during occupation TON and "Roch" operated under the influence of political forces related with London emigration, "Roch" educational activists joined the Polish People's Party led by the Prime Minister of the emigration government, Stanisław Mikołajczyk ${ }^{11}$. Therefore, the Polish People's Party, whose approaches were incompliant with the workers' parties in the educational policy, was strongly criticised by the Polish Workers' Party activists.

During the Polish People's Party Congress held in Warsaw, on 19-21 January 1946 a statement was made regarding the necessity to "quickly enter the path to the implementation of the idea of universal youth education at a secondary level as of ending primary school until 18 years of age" 12 . According to the convention participants, popularisation of the secondary school was to be executed via various paths, but above all, it was postulated to popularise schools in the countryside.

Educational resolutions of the Polish People's Party Congress and speeches made by the Minister Wycech, who managed the Education Commission's work during the Congress, came under strong pressure of the Polish Workers' Party's educational activists, the more so, as at that time the Vice-Prime Minister, Stanisław Mikołajczyk was the head of the Ministry.

On 23-24 March 1946, in Warsaw the Conference was held during which approaches regarding the school reform of the Polish Socialist Party and the Polish Workers' Party's teachers, were agreed on. The final decision included resolutions on the necessity of the Polish Workers' Party and the Polish Socialist Party to oppose any attempts of hindering

\footnotetext{
9 Ibidem, p. 107.

${ }^{10}$ Ibidem, p. 108.

11 Ibidem, p.109.

12 AZHRL, Kongres PSL, II PSL - 37, p. 128; As cited in: MAUERSBERG, S., op. cit, p. 109.
} 
the implementation of already started school reform. The necessity to start in the consecutive year a 8 form primary school and to eliminate the 1 form lower secondary school as well as to start works on extending the future secondary school based on 8 form primary school, was underlined. The conference declared itself in favour of eliminating new-entrant forms, which were, in their opinion, a disguised type of a first form of lower secondary school and therefore, contradicted the principle of school uniformity ${ }^{13}$.

The issue of the school reform implementation was also discussed during the $1^{\text {st }}$ Democratic Political Party Congress held in July 1946. At this event, a speech given by Eugenia Krassowska was of a crucial meaning. The speaker accused the Ministry of limiting the possibility of increasing the organisational level of urban and rural schools. Both, Krassowska and whole Democratic Political Party were in favour of implementing a highly organised school as soon as possible. Under the influence of the paper presented by Krassowska and upon request of the Cultural and Educational Committee, the Congress called on the government to immediately start introducing full 8 form schools and as of 1 September 1946 ceased establishing new-entrant forms in lower secondary schools. Furthermore, it was postulated that all educational issues were concentrated in one ministry. Moreover, the Congress demanded a position of Minister or Vice-Minister of Education which resulted in appointing Eugenia Krassowska to the position of Undersecretary of State in the Ministry of Education ${ }^{14}$.

The scope and pace of the school reform implemented by the Ministry of Education was still strongly criticised by the left-wing teachers; however, at the end of 1946, the Polish Socialist Party became the main source thereof, whereas the Polish Workers' Party's academics gave its opinion on this matter in an increasingly reserved and careful manner ${ }^{15}$.

The Education Congress of the Polish Socialist Party held on 8-10 December 1946 recognised the hitherto manner of implementing the school reform as insufficient and it was decided to repeat theses included in the paper by the Warsaw Chief Education Officer, Teofil Wojeński, presented during the last, aforementioned Congress, who claimed that:

1) the essence of the school reform does not consist in adding a form to the primary school, but in popularising teaching at a secondary level and in uniform ideological direction of school;

2) the character and pace of school reform must be adjusted to the character and pace of political and social transformations;

3) the school reform should be implemented wherever it is possible, and not only in some regions ${ }^{16}$.

13 The Polish Scouting and Guiding Association, the Polish Socialist Party Department, the Education and Culture Division. Protokół z konferencji aktywu nauczycieli PPR i PPS w dniu 23 i 24 III 1946 w CKW PPS, 235/XVII - 6, p. 10; As cited in: MAUERSBERG, S., op. cit., p. 112-113.

14 Ibidem, p. 112.

15 Ibidem, p. 121.

16 Wychowanie nowego człowieka, Pierwszy dzień obrad Kongresu Oświatowego PPS, Robotnik, 9.12.1946, no. 239; As cited in: MAUERSBERG, S., op. cit., p. 121. 
The Congress deemed then implemented reform insufficient and called on repeating the aforementioned theses as well as on teachers' ideological cooperation with working class and peasant movement both, as it was claimed, for the purposes of strengthening democratic gains and redevelopment of the nation's psychological attitude.

On 19 January 1947, elections to the Legislative Sejm were held, which resulted in a significant weakening of the Polish People's Party's impact. Furthermore, the party itself split and the opposition against Stanisław Mikołajczyk and his closest co-workers was growing.

As soon as during first session of the Sejm, a new direction of the educational policy was clearly signalled and the necessity of the so-called democratisation of upbringing was underlined, which in practice simply meant starting a decisive ideological offensive in schools.

The Prime Minister Józef Cyrankiewicz (the Polish Socialist Party) presented in his exposé on 19 June 1947 achievements of the Polish education and underlined that the government is especially concerned with the democratisation of education and bringing the youth up in the spirit of people's and national democracy ${ }^{17}$.

Stanisław Skrzeszewski (the Polish Workers' Party) was re-appointed as the Minister of Education in Cyrankiewicz's government. Moreover, educational authorities were significantly changed in personal respect. The Polish People's Party's members left the Ministry of Education's management. All 5 chief education officers being members of the Polish People's Party were recalled. Among 14 chief education officers -4 were members of the Polish Workers' Party, 4 - the Polish Socialist Party, 3 - the People's Party and 2 the Alliance of Democrats. 375 changes were made on positions of school inspectors and subinspectors ${ }^{18}$. Those changes indicate a decisive turn in the national educational policy.

In summer 1948, stark differences in attitudes and approaches within the conception of the Polish path to socialism were revealed among the management of the Central Committee of the Polish Workers' Party. Władysław Gomułka was removed from the position of the General Secretary of the Central Committee of the Polish Workers' Party and Bolesław Biuret was appointed to this position. The new party management undertook a general ideological offensive, also in the educational and didactical scope.

On 30 October 1948, the Polish Workers' Party's educational activists met at a national council in Warsaw with an objective of specifying educational tasks in the conditions of an ongoing battle for ideology, contents and methods of teaching. The hitherto educational policy was criticised and blamed for delaying ideological and organisational redevelopment of schools ${ }^{19}$. During his speech, the Minister Skrzeszewski criticised too slow changes in curricula and course books, neglecting countryside schools and indolent reorganisation of secondary schools. Whereas, as achievements he listed structural redevel-

${ }^{17}$ Stenographic report on the session of the Legislative Sejm on 8 February 1947, column 34; As cited in: MAUERSBERG, S., op. cit., p. 150; p.181-182.

18 Ibidem, p. 182.

19 Ibidem, p. 234. 
opment of elementary and secondary schools. Final resolutions of the council regarded, among others, a wider availability of secondary schools, revisions of curricula at all levels, basing the upbringing system on principles of Marxism-Leninism and linking upbringing work with ideological youth organisations ${ }^{20}$.

A similar atmosphere accompanied the educational activists' conference held on 15 November 1948. The hitherto educational policy of the Polish Socialist Party was criticised and it was recommended, among others, to establish a uniform school organisation system, improving the level of countryside schools' organisation, improving the access of farmers' and workers' children to secondary schools, revising curricula and course books, providing the youth with ideological care, organisational and programme redevelopment of the Polish Scouting and Guiding Association, nationalization of all schools ${ }^{21}$. The then Minister of Education Henryk Jabłoński in his paper presented at the Conference stated that the upbringing and ideological objectives had not yet been clearly defined and the curricula and course books included traditionalist and nationalist contents ${ }^{22}$.

It is worth adding that after dramatic events in 1947 (the Polish People's Party's defeat in elections, an internal split in the party, escape of S. Mikołajczyk), two parties were established, i.e. the People's Party and the Polish People's Party. In May 1948, those parties signed a declaration of cooperation and unity of actions; therefore, they adopted an alliance of workers and farmers. As a consequence, the parties turned to the development of socialist and internationalist upbringing ${ }^{23}$.

\section{Public and private secondary schools in post-war Poland in the context of system changes}

The Polish state's post-military actions, limited budget possibilities resulted in the fact that despite public secondary schools ${ }^{24}$, there were also quite a lot of private secondary schools in Poland ${ }^{25}$. On 1 December 1945, from among 705 secondary schools -383

${ }^{20}$ Ibidem, p. 234-235.

21 Ibidem, p. 236.

${ }^{22}$ JABŁOŃSKI, H., "Polityka oświatowa w Polsce Ludowej”, Wiedza i Życie, 1948, no. 12, p. 1050; As cited in: MAUERSBERG, S., op. cit., p. 236.

${ }^{23}$ AZHRL, People's Party, SL/34; As cited in: MAUERSBERG, S., op. cit., p. 238.

${ }^{24}$ Statehood of secondary schools was a priority in opening those establishments.

25 The Ordinance of the Minister of Religion and Public Education of 5 July 1939 (Official Journal, the Minister of Religion and Public Education/No. 7/item 179) on the organisation of public secondary school (high school and lower secondary school) stipulated that each secondary school can exist on the grounds of an organisational order issued therefor. In the first month after the liberation of Poland, while organising education, secondary school was activated as a public institution, although it had not been such an institution before 1939, and it was functioning despite the fact that it had not received the Minister's decree. Furthermore, secondary schools existing before the war were either male, or female institutions. After the war, they were transformed into coeducational schools. Moreover, high school divisions and the school name e.g. its patron were often changed. With time, this situation was regulated on the grounds of lists sent to the Ministry by particular School District 
were public and 322 were non-public, whereas, in some voivodeships (among others: Warsaw, Krakow, Lubelskie) a number of non-public schools doubled the number of public schools ${ }^{26}$.

The Ministry of Education agreed to the existence of private schools ${ }^{27}$, since those school unburdened the public budget. However, due to ideological reasons, the left wing had serious reservations as to the existence of secondary schools run by religious congregations. In the beginning those schools were tolerated, however, their number halved soon after the war. Before the war religious congregations ran 86 secondary schools with 12.5 thousand of students, whereas, in spring 1946 there were only 44 of them with 6.5 thousand of girls and boys. Religious upbringing was applied therein, the youth participated in obligatory religious practices and belonged to the Sodality of Our Lady. This activity worried the MPs of the People's Party with Jan Rusin in the lead, who in April 1946 accused the Ministry of Education that it gives education to religious congregations. Whereas, on 12 June, in response to the allegations the Ministry sent a letter to the Board of the State National Council, in which it referred to the legal grounds of religious congregation schools pursuant to the March Constitution and the Act of 11 March 1932 on private schools. The Ministry explained that after the war the number of schools run by religious congregations halved in comparison to the pre-war number ${ }^{28}$.

Decreasing trends for those schools still existed, as in the school year 1947/48 there were 42 catholic secondary schools with 8 thousand of male and female students, of which one third lived in boarding houses.

Public authorities quite effectively harassed Catholic schools in order to limit their number. It was executed, among others, by attempting to establish anti-Christian organisations therein - Zwiazek Walki Młodych (Youth Fight Association) or Organizacja Młodzieży Towarzystwa Uniwersytetu Robotniczego (Youth Organisation of the Workers' University Association), playing a diversionary role against the Catholic upbringing. Furthermore, there was an absolute ban on establishing youth Catholic organisation in schools. Moreover, parents were induced to transfer their children from Catholic to public schools. Some catholic schools were revoked the rights of public schools and if such rights were given, it was done at last possible moment and only for one school year, which cre-

Inspectorates, the Ministry of Education, the Department of Secondary Education. The issue of changing the organisation of public secondary schools, AAN, Team 283, file no. 1575/2.

26 The Ministry of Education. Szkolnictwo w liczbach 1945/46, p. 26, 39.

${ }^{27}$ In the Order we read that such a school should be organised in imitation of a public institution. In the annex thereto constituting a form to be filled in by a private school applying for a consent, one of the points states that the school management should stipulate the degree to which the school fulfils public and social tasks. This issue decidedly indicates the emphasis then authorities put on full control over private education, despite the fact that in the first years post-military actions, it had not been paid attention to as much. The Order of the Minister of Education of 19 March 1945 (No. II-Śr. 2220/45) on giving the rights of public schools to private secondary schools, teacher education institutions and basic vocational schools, Official Journal of the Minister of Education 1945/no. 1/item 3 .

${ }^{28}$ AMO, Office of the Minister, the Presidential Department, 4/27; As cited in: MAUERSBERG, S., op. cit., p. 129-30. 
ated an atmosphere of anxiety and uncertainty among teachers and students that was overcame by persecuted headmasters and teachers with great difficulty ${ }^{29}$.

Communist authorities searched for various excuses to close Catholic schools, and if they could not find any, they simply notified the management of a given school that "it had not been included in the school network for the nearest school year" ${ }^{\prime 3}$. Another method was to deprive a specific school year by year of the right to recruit students to the first form, which resulted in a slow extinction of the school and its premises and equipment being the property of religious congregation were usually confiscated to the benefit of public schools ${ }^{31}$.

The worsening political situation in Poland resulted in closing in 1948 a number of Catholic schools and the ones that were left were taken over by the state. As written in the Episcopate's letter to the President B. Biuret, the situation "is contrary not only to the freedom of conscience and religion, but it is simply interfering in the internal life of the Church. The Church's explicit and basic rights include a possibility of running Catholic schools attended by children of Catholic parents, since a vast majority of Polish society are devout Catholics. The secularisation of all schools in Poland, [...] violates the freedom of religion guaranteed in the Constitution ${ }^{32}$."

Private secondary schools were significantly limited with regard to introducing 11-year olds in the school year 1948/49 and it was ideologically imposed, among others, by Teofil Wojeński, who in his paper presented during the convention of chief education officers in August 1947, spoke against the existence of schools constituting a private property of persons and religious congregations. In Wojeński's opinion "those schools are profit-driven or constitute the Church's tool in fighting for souls of the young generation, are ideologically foreign and endanger the youth with conflicts with surrounding social reality." Wojeński recommended eliminating those schools by hindering their further development and then, nationalising the ones compliant with then official educational spirit, which were at the same time necessary due to the school network and social needs ${ }^{33}$.

In the years 1944-1948, in Poland there were both, public and private secondary schools. Public schools had a slight numerical advantage. Until 1950, the scope of private schooling was significantly limited. Secondary school secularisation after the year 1948 was of course related with ideological offensive undertaken in the school system aimed at the standardisation of didactical and educational work of schools and establishment of

${ }^{29}$ KRYŃSKA, E., MAUERSBERG, S., Indoktrynacja młodzieży szkolnej w Polsce w latach 1945-1956, Białystok 2003, p. 17-18.

${ }^{30}$ Letters of cardinals A. Hlond and A. Sapieha of 24 June 1948 to the President B. Biuret and the Bishop Z. Choromański, the Secretary of the Episcopate, of 23 August 1948 to the Ministry of Education; As cited in: RAINA, P., Kościót w PRL. Kościót katolicki a państwo w świetle dokumentów 1945-1989, vol. 1: Lata 19451959, Poznań 1994, p. 127; p. 128; p. 130; p. 131.

31 Ibidem.

32 Letter of the Polish Episcopate to the President B. Biuret regarding the situation of the Church in Poland (22 December 1948), [in:] RAINA, P., op. cit., p. 137.

${ }^{33}$ WOJEŃSKI, T., “Zagadnienie szkolnictwa prywatnego”, Nowa Szkoła, 1947/48, no. 2/3. 
mutual ideological platform. In such situation private schools and especially the ones run by religious congregations could no longer function, as they did not meet the requirements of then educational authorities ${ }^{34}$.

Statistical materials published by the Ministry of Education in the years 1945-1948 present a division of secondary schools into public and private (table). On the grounds of published school statistics, the secondary schools' secularisation process cannot be fully tracked. However, it can be stated that the scope of the private schools' influence in Poland was explicitly limited ${ }^{35}$.

Table. Public and private secondary schools in Poland in the years 1945/46 - 1948/49 ${ }^{36}$. Estimate data.

\begin{tabular}{|c|c|c|c|c|c|}
\hline \multirow{2}{*}{ Years } & \multirow{2}{*}{$\begin{array}{c}\text { A general number } \\
\text { of schools }\end{array}$} & \multicolumn{4}{|c|}{ A number of schools } \\
\cline { 3 - 5 } & & public & $\%$ & private & $\%$ \\
\hline $1937 / 1938$ & 777 & 308 & 39.6 & 469 & 60.4 \\
$1945 / 1946$ & 705 & 384 & 54.5 & 321 & 45.5 \\
$1946 / 1947$ & 758 & 442 & 58.3 & 316 & 41.7 \\
$1947 / 1948$ & 742 & 469 & 63.2 & 273 & 36.8 \\
$1948 / 1949$ & 823 & 617 & 75.0 & 206 & 25.0 \\
\hline
\end{tabular}

\section{Elimination of religious education in secondary schools during school system redevelopment in post-war Poland}

Polish people's government as of its beginning sought to introduce and enforce the principle of separating the Church from the state. Those declarations were stipulated by Polish communists in general terms in the Programme Declaration of the Polish Workers' Party entitled: "What are we fighting for?" from November 1943, as they confirmed their approach in the Manifesto of the Polish Committee of National Liberation of July 1944.

In the context of the declaration, the redevelopment of the Polish school system started and its basic objective was to change the school system: its organisational grounds and, first of all, the hitherto upbringing ideology. By recognising in a sense the heritage and past achievements of the Polish education, the authorities started fighting for a new ideological image of the school.

One of the basic elements of said fight became the issue of teaching religion and religious upbringing in schools and outside of schools. In the new political situation it was

${ }^{34}$ MEISSNER, A., "Kształtowanie się sieci średniego szkolnictwa ogólnokształcącego w Polsce w latach 1944-1950”, Rocznik Komisji Nauk Pedagogicznych, 1984, vol. 32, p. 64-65.

35 Ibidem, p.64.

${ }^{36}$ Szkolnictwo w liczbach 1945/46, Warsaw 1946, p. 26; Przyczynki statystyczne, NB 1, Warsaw 1947, p. 36; "Szkolnictwo w roku szkolnym 1947/1948 w liczbach tymczasowych", Rocznik Statystyczny, 1947, p. 160 and 1949, p. 206; Statystyka szkolnictwa w latach 1945/46 i 1946/47, GUS, Series D, NB 7, Warsaw 1948, p. 5159. 
obvious that this issue hitherto based on the pre-war legal regulations would become an area of fight between the communist authorities and the Church, the cost of which was the youth upbringing. The communist authorities wanted to change said education from public, national and religious to secular and those changes were mainly implemented in schools.

Teaching religion in post-war Poland became the subject of increasingly intensive fight of state and party authorities with the Catholic society, the fight that was expressed in various forms.

After ending military actions, when schools of all levels were dynamically established, pre-war plans of lessons were used, where two lessons of religion per week in each form, both in elementary and secondary schools, took the first place. Religion was taught, similarly as pre-war, by clergymen, catechists or teachers of secular subjects who were entrusted by the Church with the so-called canonical mission (missio canonica).

Traditional religious ceremonies also accompanied opening new schools and starting lessons. Nevertheless, then state authorities were aware that any attempts at counteracting those practices, measures aimed at limiting the presence of the Church at schools were strongly criticised by the society, clergymen, teachers, parents and the youth ${ }^{37}$.

With time the Polish communist authorities started limiting the religious education of the youth. However, this was being done quite gradually, since the authorities were aware of the strong attachment of the Polish society to teaching religion in schools and to Christian upbringing in general.

One of the fist issues regarding limiting the influence of the Church and teaching religion on children and school youth comprised depending religious education on parents' will and wishes, which in fact made religion a facultative subject. Such attitude was contrary to the provisions of the March Constitution of 1921, which basic assumptions were to be binding until adopting the new constitution ${ }^{38}$.

Then Minister of Education, Stanisław Skrzeszewski, during Łódź Convention in June 1945 stated that: "the attitude to teaching religion shall not change; in compliance with the guidelines of our Government we ensure a complete freedom of teaching religion in schools and religious practices; at the same time, in accordance to basic principles of democracy we shall not limit the freedom of conscience, we shall not use coercion in the issues regarding inner life of an individual" 39 . Earlier, he provided the same answer to the letter of worried Archbishop A. Sapieha addressed at the Ministry of Education, where the Archbishop warns against a terrible mistake that would be establishing a non-denomina-

${ }^{37}$ KONOPKA, H., Religia $w$ szkołach Polski Ludowej. Sprawa nauczania religii w polityce państwa (1944-1961), Białystok 1995, p. 11.

${ }^{38}$ Article 120 of the Constitution of 17 March 1921 stipulated that "In each academic institution, whose curricula covers education of youth below 18 years old, which is fully or partially maintained by the state or selfgovernment bodies, religion is a subject obligatory for all students", Journal of Laws of the Republic of Poland 1921/no. 44/item 267.

39 Ogólnopolski Zjazd Oświatowy w Lodzi 18-22 czerwca 1945 roku, Warsaw 1945, p. 59. 
tional and materialistic school. With regard to the matters referring to teaching religion, he wrote: "A facultative character of teaching religion, its non-obligatory nature and dependence on parents' wishes must be a priority. This arbitrariness is contradictory with Article XIII of the Concordat ${ }^{40}$ concluded with the Holy See that has been hitherto binding. Furthermore, it is contrary to the provisions of the Polish Constitution as well as the Constitution of 17 March $1921^{41}$ Article 120, which the present Provisional Government deems as binding. Finally, he opposes the factual statement of the Prime Minister [Edward Osóbka-Morawski] made to the representatives of foreign press in Moscow that "the Provisional Government not only puts no obstacles to the Catholic Church, but on the contrary, did everything to provide the Church in Poland with proper conditions" ("Dziennik Polski" 1945/No. 83, p. 3). Not only us, the Bishops, but also a vast majority of parents of various political views oppose this project and demand such a basic subject, that is, religion not to be treated as redundant and less valuable." 42

The problem of Polish school's secularity, far broader than the issue of teaching religion was perceived by particular parties in a different manner. Representatives thereof did not in fact express an open attitude regarding teaching religion, however, both, the Polish Socialist Party and the People's Party saw laicisation of the Polish school through removing religion from curricula. During Łódź Convention the representative of the Central Military Commission of the People's Party, Wilhelm Garncarczyk said that "we, members of peasants' parties, fully stand on the grounds of a secular school and we do not see the need to teach religion in schools as an obligatory subject. We have churches to that end, where we send our children." ${ }^{43}$ This opinion is shared by the Polish Socialist Party, which saw the necessity of "separating religion from state and school" 4 . In this matter the Polish People's Party took a more careful approach, since there were many Catholics in this party, therefore, the party was not interested in laicisation of the Polish school ${ }^{45}$.

Despite expectations, as of 25 June 1945 the new Minister of Education in the Provisional Government of National Unity, the member of the Polish Teachers' Union and the Polish People's Party, Czesław Wycech did not change the direction of educational authorities' actions in the scope of teaching religion and religious practices in schools.

The issue of teaching religion in schools, that is, limitation thereof, required solving at least two legal problems, namely agreements resulting from the concordat and provisions of the March Constitution. The Resolution of the Provisional Government of

${ }^{40}$ Concordat between the Holy See and the Republic of Poland of 10 February 1925, Journal of Laws of the Republic of Poland 1925/no. 72/ item 501.

41 The Constitution of the Republic of Poland of 17 March 1921, Journal of Laws of the Republic of Poland 1921/no. 44/item 267.

42 AAN, MO, file no. 411, Letter of the Archbishop A. S. Sapieha of 5 June 1945 to the Minister S. Skrzeszewski; 17 lat nauczania religii w Polsce Ludowej. Wybór dokumentów, (PUB) H. KONOPKA, Białystok 1998, p. $21-22$.

${ }^{43}$ Ogólnopolski Zjazd Oświatowy..., p. 114.

${ }^{44}$ Barykada Wolności, 30.06.1945, no. 1.

45 JAKUBOWSKI, J., Polityka oświatowa PPR 1944-1948, Warsaw 1975, p. 193. 
National Unity of 12 September 1945 on expiry of the concordat solved the first problem. Whereas, in the case of the second one, the Council of Ministers referred to the opinion of the Legal Commission at the Ministry of Justice drawn up in August $1945 .{ }^{46}$ As a result of the Legal Commission's decisions, on 13 September 1945 the Minister of Education, $\mathrm{Cz}$. Wycech issued a circular regulating teaching religion in $\mathrm{schools}^{47}$, in which he "releases children from the coercion to learn religion in school", since Article 111 of the March Constitution guaranteed freedom of conscience and religion to all citizens (despite the fact that Article 120 of this Constitution talked about the obligatory character of teaching religion in schools). Therefore, the Minister ordered as follows: 1) religion in public schools is a subject obligatory for all students belonging to denominations recognised by the state; 2) students whose parents declare they do not wish their children to learn religion are dismissed from this subject; 3 ) those children do not receive a mark from religion on their certificate $^{48}$.

The Circular of 13 September 1945 established new legal grounds wherein the Ordinance of the Minister of Religion and Public Education of 9 December $1926^{49}$ and the "Bartel's Circular" of $1927^{50}$ in fact ceased to be binding. This Circular was supported by governing parties: the Polish Workers' Party and the Polish Socialist Party. Enforcement of the Circular of 13 September 1945 did not cause bigger problems. It was enforced, among others, by eliminating religion as a high school finals' subject in pedagogical high school in June 1945, removing teaching religion from schools for adults, decreasing the number of hours of this subject in vocational schools, detaining religion course books in censorship ${ }^{51}$.

Such actions of the Ministry of Education elicited the Church's reaction, which in the situation of growing ideological offensive of authorities, started actions aimed at strengthening its position in the state. In the memorial of 15 September 1946, it argued, among others, with the attitude of the Minister of Education $-\mathrm{Cz}$. Wycech, underlining the fact that the Minister's Circular forces religion into the group of facultative subjects, since the question arose how to combine its allegedly obligatory character with the possibility of issuing valid school certificates without marks from religion. According to the Episcopate, decreasing the importance of teaching religion in schools resulted in decreasing its value

46 "Dwie opinie prawne z dziedziny stosunków Kościoła i państwa”, Demokratyczny Przegląd Prawniczy, 1945, no. 1; JABŁOŃSKI, K. H., “Aspekty prawne nauczania religii w Polsce Ludowej”, Zeszyty Naukowe Uniwersytetu Jagiellońskiego, 1983/NB 9, p. 68; As cited in: KONOPKA, H., op. cit., p. 16.

${ }^{47}$ Circular no. 50 of 13 September 1945 on teaching religion in schools, Official Journal of the Ministry of Education 1945/no. 4/item 189.

48 KRYŃSKA, E., MAUERSBERG, S., op. cit., Białystok 2003, p. 15.

49 The Ordinance of the Minister of Religion and Public Education of 9 December 1926 on teaching Catholic religion in schools, Journal of Laws of the Republic of Poland, 1926/no. 1/item 9.

${ }^{50}$ Circular of the Minister of Religion and Public Education to District Schoolboards on teaching religion in public schools, Journal of Laws of the Republic of Poland, 1927/no. 2/item 32.

${ }^{51}$ RAINA, P., op. cit., p. 33-41. 
in the opinion of students and society and furthermore, clashed with the Polish tradition, which deemed religious education as the first and the most important school obligation ${ }^{52}$.

After adopting the Small Constitution on 19 February 1947 the educational authorities assumed Notes on some issues in constitutional acts of 4 and 19 February 1947 (Uwagi o niektórych zagadnieniach ustaw konstytucyjnych z 4 i 19 lutego 1947 roku) ${ }^{53}$ as a reliable interpretation of the issue of teaching religion. The Small Constitution not only did not annul the March Constitution and the July Manifesto of the Polish Committee of National Liberation, but on the contrary, at the beginning stated that the Constitution is based on the fundamental assumptions thereof. Since no article from the March Constitution regarding the school system and teaching was referred in the new Constitution, it was acknowledged that in this scope the legislator is not subject to any prior limitations of the Constitution ${ }^{54}$. Also the concordat constituting the second legal grounds of teaching religion in schools ceased to be binding in compliance with the government declaration of 1945; the Ministry of Education adopted the interpretation that the majority of ordinances, circulars etc. regarding teaching this subject and referring to the March Constitution and concordat became invalid and gave the government full freedom in new regulation of this issue ${ }^{55}$.

After the Bloc of Democratic Parties' win in elections in January 1947, Stanisław Skrzeszewski was reappointed as the Minister of Education. After elections, in the changing political situation, matters regarding teaching religion and promoting religious contents in school had new repercussions. In the Legislative Sejm the Catholic environment was represented by: Jan Frankowski, Aleksander Bocheński and Witold Bieńkowski. The Catholic Social Club constituted quite a weak opposition against communists. However, this group showed a significant political activity. Representatives of different ideological-educational directions several times clashed directly in the Sejm. Among others, the Catholic MP Witold Bieńkowski underlined that the educational policy of the Polish state is detrimental to the idea of combining all citizens in the public service, since e.g. tendencies of nationalising all schools are contradictory to the interests of Catholics, who want to have own religious schools. He underlined that Catholics for whom upbringing belongs to the family, state and the Church, would not resign from the upbringing influence of the Church. Witold Bieńkowski demanded compliance of curricula with principles of Catholic dogma and ethics and freedom of youth religions organisations' activity in schools ${ }^{56}$. This speech was supported by the Polish People's Party's parliamentary club, represented by the MP, Wincenty Bryja. He stated that his party would vote against the

52 RAINA, P., op. cit., p. 36.

53 "Uwagi o niektórych zagadnieniach ustaw konstytucyjnych z 4 i 19 lutego 1947 r.", Demokratyczny Przegląd Prawniczy, 1947, no. 3.

${ }^{54}$ AAN, MO, file no. 414, An overview of provisions on teaching Roman Catholic religion for the period before passing the Small Constitution of 1947; As cited in: KONOPKA, H., op. cit., p. 24.

${ }_{55}$ KONOPKA, H., Podstawowe uregulowania prawne nauczania religii $w$ powojennej Polsce (19441956), [in:] Białostockie Teki Historyczne, vol. 1, Białystok 1995, p. 103-129.

56 “Wielka mowa posła Bieńkowskiego", Stowo Powszechne, 21.06.1947. 
Ministry of Education's budget, since "the present Minister of Education in his programme and activity clearly follows the path to party-orientation of the national education" 57 .

Such a course of events forced the Catholic Church to start actions that were to strengthen its position in the state. In March 1947 the Episcopate presented the memorial to the Prime Minister regarding constitutional postulates, in which it demanded that the Constitution gave a Christian and denominational character to the Polish state and provided the Church with broad entitlements including, among others, running educational institutes, running schools and teaching religion in all public and private schools ${ }^{58}$.

Apart from the Church, the Labour Party promoted upbringing based on Christian morality and philosophy. By underlining the ideas of humanism and Christianism, the Labour Party stressed the need of the Church's participation in upbringing work, at the same time supporting the autonomy and independence of the school system from political and administrative authorities ${ }^{59}$.

The atmosphere of mutual mistrust thickened in autumn 1947. One of the state authorities' policy tools regarding teaching religion in schools comprised issuing ordinances and implementing provisions in administrative mode, more and more often resigning from announcing them in the Journal of Laws or the Official Journal of the Ministry of Education. In autumn 1947 the Minister of Education sent the draft of the ordinance regarding teaching religion in schools to district schoolboards. Therein, he ordered to oppose outgrowth of clericalism and bigotry, using teaching religion by prefects for other purposes. He also underlined the necessity to provide access of the youth solely to the religion course books approved by the Ministry of Education ${ }^{60}$.

Another incident happened during session of the Sejm Fiscal and Budget Commission, and then, at the Sejm forum during the budget session in December 1947 with regard to school authorities recalling some religion teachers and especially monks and nuns due to, as specified, using religion classes for anti-socialist propaganda.

In the context of the aforementioned events, on 23 May 1948 (on the eve of Poznan Convention) a pastoral letter of the Polish Episcopate to parents and youth was read from pulpits. In the letter, the addressees were warned against the danger of materialising life by apostasy. Religious education and practices as well as maintaining living faith in human affinity to God were encouraged. In-depth studies that should allow understanding that the matter is not everything and that a man does not live on bread alone were induced ${ }^{61}$.

${ }^{57}$ Stenographic report on the session of the Sejm on 20 June 1947, column 38; As cited in: MAUERSBERG, S., op. cit., p. 197.

${ }_{58}$ KOŁOMEJCZYK, N., SYZDEK, B., Polska w latach 1944-1949, Warsaw 1971, p. 183-185; As cited in: MAUERSBERG, S., op. cit., p. 196.

59 Tezy programowe Stronnictwa Pracy, Warsaw 1946, p. 13-14; As cited in: MAUERSBERG, S., op. cit., p. 196-197.

${ }^{60}$ AAN, MO, file no. 414, A draft on teaching religion in schools to District Schoolboards; As cited in: KONOPKA, H., op. cit., p. 31.

${ }^{61}$ Pastoral letter: "Ukochani Rodzice - Droga Młodzieży Polska!", Tygodnik Warszawski, no. 23 of 06.06.1947; As cited in: MAUERSBERG. S., op. cit., p. 198. 
Ideological issues touched upon in the letter were only a pretext, as in fact, the Episcopate's letter and Catholics' action in the Sejm were symptoms of the Church's fight against educational policy of new school authorities operating under guidance of the Central Committee of the Polish Workers' Party. The Church was aware that the policy is aimed at socialist upbringing of the youth, therefore it used various arguments to counteract $\mathrm{it}^{62}$.

Until the school year 1947/48 inclusive, religion was taught in all schools. Despite the fact that the scope thereof was in many cases limited, the classes were conducted. It happened, because religion as an obligatory subject was included in curricula and it was still in the first place in lesson plans ${ }^{63}$.

First post-war years in the Polish school system explicitly show that the process of systematically forcing out teaching religion and religious practices from all levels of education, also from secondary schools, started. Those changes falsely motivated with the necessity to adhere to the principles of freedom of conscience and religion, led to the school system laicisation. This effective forcing the Church out from schools and therefore, from the education of the young generation was aimed at establishing a new, socialist society in the future.

\section{Bibliography}

Sources

Archiwum Akt Nowych (AAN), Zespół 283, sygn. 1575/2 (Archive of Contemporary Records, Team 283, file no. 1575/2)

„Barykada Wolności”, no. 1, 30.06.1945

Dziennik Urzędowy Ministerstwa Oświaty 1945/Nr1/poz.3 (Official Journal, the Ministry of Edocation 1945/no1/item 3)

Dziennik Urzędowy Ministerstwa Oświaty 1945/Nr2/poz. 62 (Official Journal, the Ministry of Edocation1945/no 2/item 62)

Dziennik Urzędowy Ministerstwa Oświaty 1945/Nr4/poz.189 (Official Journal, the Ministry of Edocation 1945/no 4/item189)

Dz. Urz. Resortu Oświaty 1944/Nr1 (Official Journal of the Department of Education 1944/no. 1)

Dziennik Ustaw RP 1921/Nr44/poz.267 (Journal of Laws of the Republic of Poland 1921/no. 44/ item 267)

Dziennik Ustaw RP 1925/Nr72/poz.501 (Journal of Laws of the Republic of Poland /no. 72/item 501)

Dziennik Ustaw RP, 1926/Nr1/poz.9 (Journal of Laws of the Republic of Poland Education1926/ no.1/item 9)

Dziennik Ustaw RP, 1927/Nr2/poz.32 (Journal of Laws of the Republic of Poland 1927/no. 2/item 32)

Ministerstwo Oświaty. Szkolnictwo w liczbach 1945/46 (The Ministry of Education. Szkolnictwo w liczbach 1945/46)

\footnotetext{
62 Ibidem, p. 199.

${ }^{63}$ KONOPKA, H., op. cit., p. 33.
} 
Konstytucja RP z 17 marca 1921r., Dz. U. RP 1921/Nr44/poz.267 (The Constitution of the Republic of Poland of 17 March 1921, Journal of Laws of the Republic of Poland, 1921/no.44/item 267)

Ogólnopolski Zjazd Oświatowy w Łodzi 18-22 czerwca 1945 roku, Warsaw 1945

Przyczynki statystyczne, NB. 1, Warsaw 1947

Rocznik statystyczny 1947

Statystyka szkolnictwa w latach 1945/46 i 1946/47, GUS, Warsaw 1948, Series D, NB 7

Szkolnictwo w liczbach 1945/46, Warsaw 1946

Szkolnictwo w roku szkolnym 1947/1948 w liczbach tymczasowych

„Demokratyczny Przegląd Prawniczy” 1947/no.3

„Słowo Powszechne”, 21.06.1947

\section{Studies}

JAKUBOWSKI J., Polityka oświatowa PPR 1944-1948, Warsaw 1975

KONOPKA H., Podstawowe uregulowania prawne nauczania religii w powojennej Polsce (19441956), [w:] Białostockie Teki Historyczne, t.1, Białystok 1995

KONOPKA H., Religia w szkołach Polski Ludowej. Sprawa nauczania religii w polityce państwa (1944-1961), Białystok 1995

KOSIŃSKI K., O nową mentalność. Życie codzienne w szkołach 1945-1956, Warsaw 2000

KRYŃSKA E., Mauersberg St., Indoktrynacja młodzieży szkolnej w Polsce w latach 1945-1956, Białystok 2003

MACIASZEK M., Treść kształcenia i wychowania w reformach szkolnych PRL, Warsaw 1980

MAUERSBERG St., Reforma szkolnictwa w Polsce w latach 1944-1948

MEISSNER A., Kształtowanie się sieci średniego szkolnictwa ogólnokształcącego w Polsce w latach 1944-1950, Rocznik Komisji Nauk Pedagogicznych, 1984, vol. XXXII

PĘCHERSKI M., ŚWIĄTEK M., Organizacja oświaty w Polsce w latach 1917-1969. Podstawowe akty prawne, Warsaw 1972

RAINA P., Kościół w PRL. Kościół katolicki a państwo w świetle dokumentów 1945-1989, t. 1, lata 1945-1959, Poznań 1994

WOJEŃSKI T., Zagadnienie szkolnictwa prywatnego, „Nowa Szkoła” 1947/48, no. 2/3 
